\title{
Pisum \& Ervilia Tetovac - Made in Early Iron Age Leskovac. Part One. Two Charred Pulse Crop Storages of the Fortified Hill Fort Settlement Hissar in Leskovac, South Serbia
}

\author{
Aleksandar Medović · Aleksandar Mikić · Branko Ćupina · Živko Jovanović · \\ Svetlana Radović · Aleksandra Nikolić · Nemanja Stanisavljević
}

\begin{abstract}
received / primljeno: 13.10.2010. revised / prerađeno: 29.12.2010. accepted / prihvaćeno: 03.01.2011. (C) 2011 IFVC
\end{abstract}

\begin{abstract}
Summary: A lucky find of 2,572 charred pea (Pisum sativum L.) seeds in a single archaeobotanical sample from the hill fort settlement Hissar near Leskovac represents a unique example in Bronze / Iron Age research in South East Europe. Another mass storage of bitter vetch (Vicia ervilia (L.) Willd.) from the same site and period (Brnjica cultural group, beginning of the Iron Age in the Morava valley) confirms a long tradition of the city of Leskovac region as a pulse crop production centre in modern Serbia. Both pulse storages were almost pure with small amount of admixture from other crops, mainly cereals, other pulses, such as lentil (Lens culinaris Medik.) and broad bean (Vicia faba L.), and oil/fibre plants. Both pulses were cultivated as main crops and were stored separately.

Key words: 12 th cent. B.C., archaeobotany, Brnjica cultural group, charred bitter vetch storage, charred pea storage, Hissar, Leskovac, South Serbia
\end{abstract}

\section{Introduction}

The fortified hill fort settlement Hissar in Leskovac, with the name derived from Turkish hissar, denoting fortress, is a multilevel settlement of the Brnjica cultural group, 1,350-1,000 B.C., Iron Age I in the Morava valley (Stojić et al. 2007).

The Hissar hill (341 $\mathrm{m}$ alt.) is in a strategic position over the confluence of Jablanica and Veternica rivers in river South Morava and over the greatest part of the valley of Leskovac. The valley is $50 \mathrm{~km}$ long and $45 \mathrm{~km}$ wide. The archaeological excavations at Hissar began in 1999. In the campaign of the year 2005, two

A. Medović $(\square)$

Museum of Vojvodina, Dunavska 35, 21000 Novi Sad, Serbia e-mail: arheolog2@gmail.com

A. Mikić

Institute of Field and Vegetable Crops, Maksima Gorkog 30, 21000 Novi Sad, Serbia

B. Ćupina

Faculty of Agriculture, University of Novi Sad, Trg Dositeja Obradovića 8, 21000 Novi Sad, Serbia

Ž. Jovanović · A. Nikolić · N. Stanisavljević

Institute of Molecular Genetics and Genetic Engineering, University of Belgrade, Vojvode Stepe 444a, p.fah 23, 11010 Belgrade, Serbia

S. Radović

Faculty of Biology, University of Belgrade, Studentski trg 16, 11000 Belgrade, Serbia rich pulse-crop samples were gathered from the deposits of the Brnjica II a-level from 12th cent. B.C. Out of 7 litres of earth substrate, a total number of 2,572 charred seeds of pea (Pisum sativum L.) and 3,031 charred seeds of bitter vetch (Vicia ervilia (L.) Willd.) were yielded through flotation, respectively. In the previous archaeobotanical report (Medović 2005), only one uncertain record of pea from the deposits of Brnjica cultural group was made, whereas 37 charred items of bitter vetch in every fourth sample were found. Beside these two species, the inventory of the pulse crops from Hissar supplements findings of broad bean (Vicia faba L.) and lentil (Lens culinaris Medik.).

\section{Materials and Methods}

The round seeds of many pulse crops cause considerable difficulties for a precise archaeobotanical determination. This is the reason why normally the so-called unidentified

\footnotetext{
Acknowledgements: The authors appreciate sincere encouragement and immense enthusiasm by Dr. Gérard Duc, a widely recognised expert in the modern grain legume genetic diversity, in its ancient counterpart.
} 
pulses-group is proportionally more numerous than Cerealia identerminata-group. Chances of carbonization of pulses and cereals in archaeological context are not equal. There are differences in chemical composition, such as high protein content in pulses vs. high starch content in cereals, as well as in processing and usage of this two crop groups. Generally, pulses have less chances of getting carbonized than cereals and are therefore underrepresented in archaeobotanical records. Mass storages of charred pulse crops, like these two lucky finds from Hissar, offer a great opportunity of getting a closer look at their cultivation, crop processing and storage methods in prehistory.

\section{Results and Discussion}

Pea

Pea is one of the first crops cultivated by humans. It is nearly impossible to determine a charred pea seed if a characteristic coffee bean shaped hilum is missing (Fig. 1). The seed-shape (spherical with some flattenings, depending on their position and space within a pod) as well as its size are not enough to say whether we are dealing with pea or not. Pea seeds can be as small as some Vicia seeds and without preserved hilum they cannot be distinguished from them. In the Hissar sample,

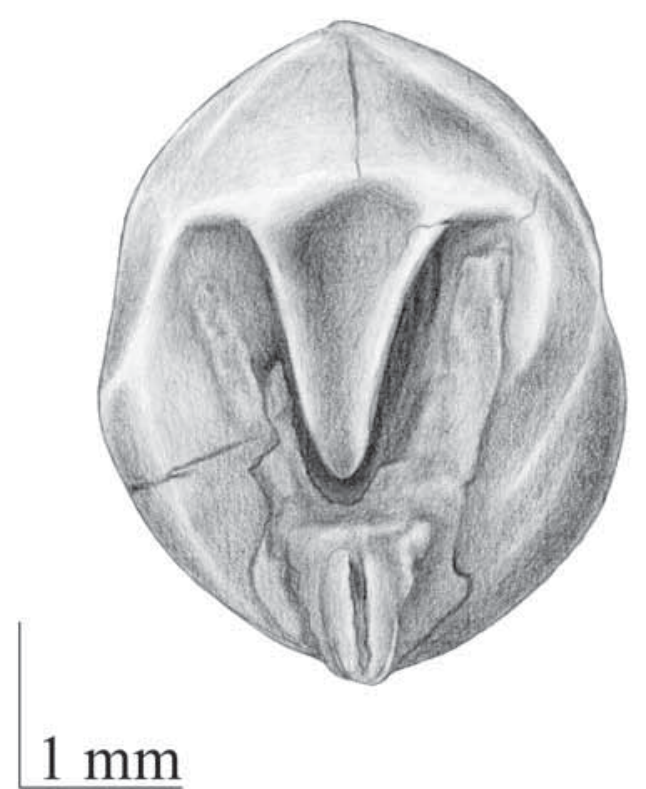

only few pea seeds maintained almost intact seed coat (testa) with hilum. Luckily, among all the pea seeds, only 32 seeds of lentil, bitter vetch and broad bean were mixed - species whose determination is undoubtful (Table 1). Lentil and bitter vetch seeds differ from pea in shape and from broad bean in size. According to the exclusion principle we can almost be sure that the rest belongs to pea.

Beside pulses, the sample consisted of few charred residues of four cereals: hulled lax eared six-row barley (Hordeum vulgare L. subsp. vulgare), bread wheat (Triticum aestivum L.), emmer (T. dicoccon Schrank) and einkorn wheat (T. monococcum L.). 320 small seeds of common millet (Panicum miliaceum L.) are not enough to change weight percentages in the sample considerably. 20 seeds of flax / linseed (Linum usitatissimum L.) and a single one-seeded nutlet of dragons head (cf. Lallemantia iberica Fisch. et C.A. Mey.) represent the taxonomic group of oil and fibre plants. Recently, archaeobotanical finds of dragons head are accumulating: in Serbia, it was recorded at the Bronze and Iron Age settlement of Feudvar (Becker \& Kroll 2008) and in the middle Bronze Age level of Židovar (Kišgeci \& Medović 2006). Both sites are located in the fertile plain of the Vojvodina region, while this is the first record of this oil plant in hilly and woody central Serbia. However, most data of charred fruits of Lallemantia come from diverse Bronze Age sites in

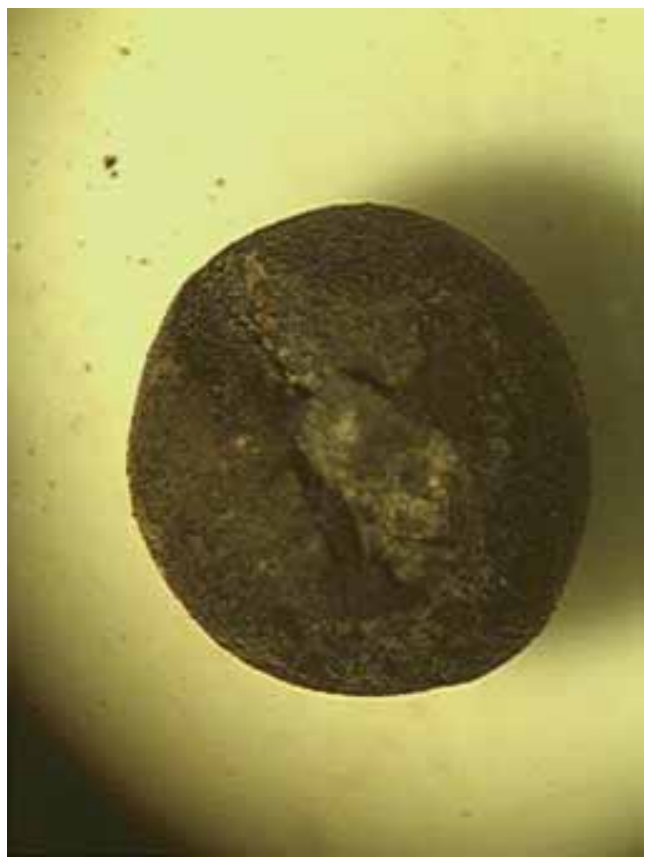

Figures 1 and 2. A charred seed of pea (Pisum sativum L.) from Hissar, Leskovac, 12th cent. B.C. A drawing by A. Medović and a photograph Slike 1 i 2 . Ugljenisano seme graška (Pisum sativum L.) sa Hisara kod Leskovca, 12. vek p.n.e. Crtež A. Medovića i fotografija 
Table 1. Hissar, Leskovac, South Serbia, 2005, Sample 35. Macrofossil plant remains (charred seeds and one seeded fruits). Brnjica II a, 12th cent. B.C. - $\mathrm{r}<0.5 \%$;

$0.5 \%<+<1.0 \%$

Tabela 1. Hisar, Leskovac, južna Srbija, 2005, uzorak 35. Makrofoslini ostaci biljaka (ugljenisana semena i jednosemeni plodovi). Brnjica II a, 12. vek p.n.e.

\begin{tabular}{|c|c|c|c|c|}
\hline $\begin{array}{l}\text { Species } \\
\text { Vrste }\end{array}$ & $\begin{array}{c}\text { Quantitity } \\
\text { Količina } \\
\text { (No.) }\end{array}$ & $\begin{array}{c}\text { Quantitity } \\
\text { Kolicina } \\
(\%)\end{array}$ & $\begin{array}{l}\text { Mass } \\
\text { Masa } \\
(\mathrm{mg})\end{array}$ & $\begin{array}{c}\text { Mass } \\
\text { Masa } \\
(\%)\end{array}$ \\
\hline \multicolumn{5}{|l|}{ Cereals / Strna žita } \\
\hline Hordeum vulgare vulgare & 10 & $\mathrm{r}$ & 126 & $\mathrm{r}$ \\
\hline cf. Triticum aestivum s.l. & 1 & $\mathrm{r}$ & 6 & $\mathrm{r}$ \\
\hline T. aestivum s.l., rachis internodes & 1 & $\mathrm{r}$ & 3 & $\mathrm{r}$ \\
\hline Triticum dicoccon & 1 & $\mathrm{r}$ & 11 & $\mathrm{r}$ \\
\hline Triticum monococcum & 1 & $\mathrm{r}$ & 2 & $\mathrm{r}$ \\
\hline Cerealia indeterminata & 1 & $\mathrm{r}$ & 8 & $\mathrm{r}$ \\
\hline \multicolumn{5}{|l|}{ Millets / Prosolika žita } \\
\hline Panicum miliaceum & 320 & 10.66 & 553 & + \\
\hline \multicolumn{5}{|l|}{ Pulses / Variva } \\
\hline Pisum sativum & 2572 & 85.68 & 62768 & 97.82 \\
\hline Lens culinaris & 21 & + & 113 & $\mathrm{r}$ \\
\hline Vicia faba & 8 & $\mathrm{r}$ & 472 & + \\
\hline Vicia ervilia & 3 & $\mathrm{r}$ & 21 & $\mathrm{r}$ \\
\hline \multicolumn{5}{|c|}{ Oil and fibre plants / Uljane i predivne biljke } \\
\hline Linum usitatissimum & 21 & + & 20 & $\mathrm{r}$ \\
\hline cf. Lallemantia iberica & 1 & $\mathrm{r}$ & 2 & $\mathrm{r}$ \\
\hline \multicolumn{5}{|l|}{ Dye plants / Bojene biljke } \\
\hline cf. Carthamus tinctorius & 1 & $\mathrm{r}$ & 2 & $\mathrm{r}$ \\
\hline \multicolumn{5}{|l|}{ Fruits / Voće } \\
\hline Sambucus & 1 & $\mathrm{r}$ & 0 & $\mathrm{r}$ \\
\hline \multicolumn{5}{|c|}{ Weeds and ruderals / Korovske i ruderalne bilike } \\
\hline Convolvulus arvensis & 16 & + & 40 & $\mathrm{r}$ \\
\hline Echinochloa crus-galli & 8 & $\mathrm{r}$ & 2 & $\mathrm{r}$ \\
\hline Fallopia convolvulus & 4 & $\mathrm{r}$ & 5 & $\mathrm{r}$ \\
\hline Chenopodium album & 3 & $\mathrm{r}$ & 0 & $\mathrm{r}$ \\
\hline Setaria viridis & 2 & $\mathrm{r}$ & 0 & $\mathrm{r}$ \\
\hline Digitaria sanguinalis & 1 & $\mathrm{r}$ & 0 & $\mathrm{r}$ \\
\hline Galium aparine & 1 & $\mathrm{r}$ & 2 & $\mathrm{r}$ \\
\hline Lolium temulentum & 1 & $\mathrm{r}$ & 3 & $\mathrm{r}$ \\
\hline Medicago & 1 & $\mathrm{r}$ & 2 & $\mathrm{r}$ \\
\hline \multicolumn{5}{|l|}{ Plant families / Biljne familije } \\
\hline Fabaceae & 1 & $\mathrm{r}$ & 3 & $\mathrm{r}$ \\
\hline Poaceae & 1 & $\mathrm{r}$ & 0 & $\mathrm{r}$ \\
\hline Total / Ukupno & 3002 & 100 & 64164 & 100 \\
\hline \multicolumn{5}{|l|}{ Other finds / Ostali nalazi } \\
\hline Insecta, larva & 1 & & 0 & \\
\hline \multicolumn{5}{|c|}{ Thousand grain weight (g) / Masa hiljadu semena } \\
\hline Pisum sativum & \multicolumn{4}{|c|}{24.40} \\
\hline Panicum miliaceum & \multicolumn{4}{|c|}{1.73} \\
\hline
\end{tabular}


northern Greece (Jones \& Valamoti 2005, Becker \& Kroll 2008). This plant, "exotic" for the Balkans, was probably introduced from Anatolia to Greece in the early Bronze Age and then cultivated locally (Jones \& Valamoti 2005). A find of safflower (cf. Carthamustinctorius L.) indicates the possible use of its flowers to dye food yellow and textile red to brown or even black. Other finds in the sample represent common weeds in millets and wheat. Although 24 taxa were found in this sample including three other pulse crops, pea is the dominant one, with a weight share of almost $98 \%$. This indicates that pea was cultivated as one of the main crops and was stored separately from the other pulse crops. The thousand grain weight of these pea seeds is $24.4 \mathrm{~g}$. Two thousand archaeobotanical samples from Feudvar yielded 3,695 Pisum records (Kroll 1998), on average 1.85 seeds per sample. The thousand grain weight of pea seeds in Feudvar was calculated in only one sample, $19.25 \mathrm{~g}$ (H. Kroll, pers. comm.) and it was $5 \mathrm{~g}$ lighter than the one from Hissar! At the archaeological sites of Židovar (Serbia) or Kastanas and Agios Mamas (north
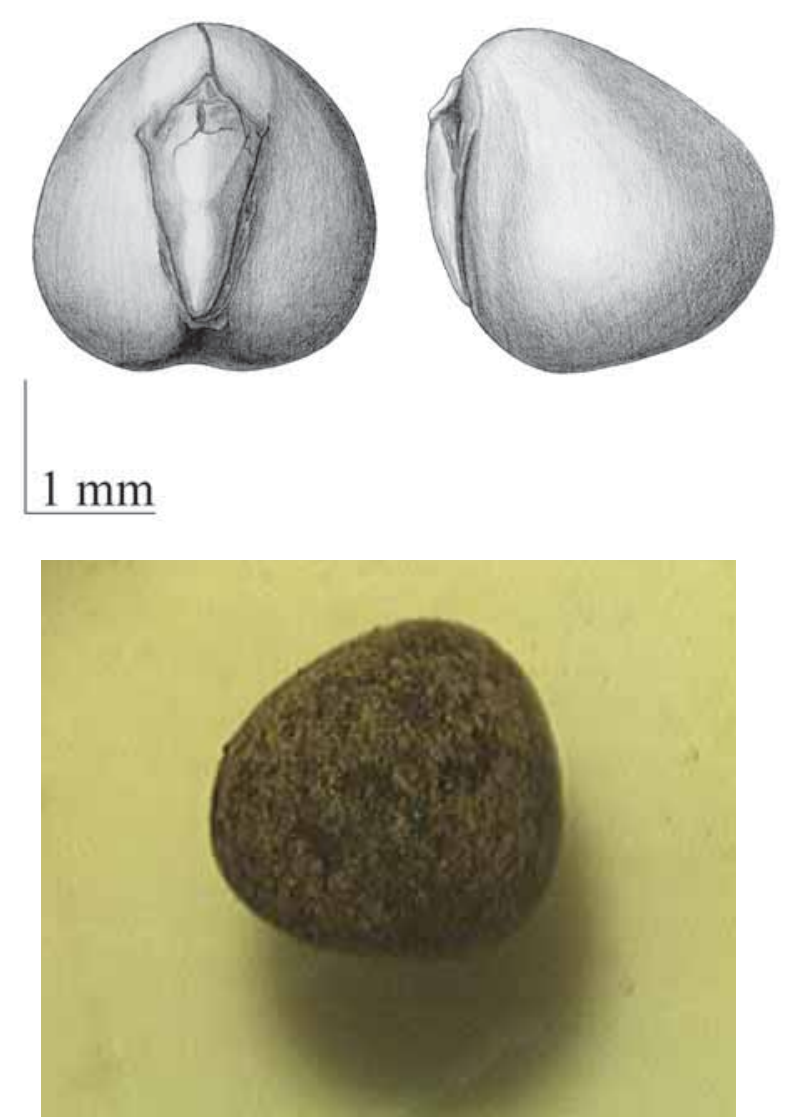

Figures 3 and 4. A charred seed of bitter vetch (Vicia ervilia (L.) Willd.) from Hissar, Leskovac, 12th cent. B.C. A drawing by A. Medović and a photograph

Slikea 3 i 4. Ugljenisano seme urova (Vicia ervilia (L.) Willd.) sa Hisara kod Leskovca, 12. vek p.n.e. Crtež A. Medovića i fotografija 
missing in charred archaeobotanical samples: its hilum is shorter than of hilum from common vetch (Vicia sativa L.) and smaller and narrower than that of pea.

Bitter vetch has been one of the essential pulse crops of the southern Balkans and adjacent areas since Neolithic (Kroll 1991). It is cultivated for its edible seeds, which are fed to livestock or eaten in soups. For human consumption the bitterness of the seeds needs to be removed through leaching by several changes of boiling water or by roasting. The species of the genus Vicia are traditionally used for feeding ruminants, particularly sheep, but they are practically unused for monogastric animals due to the toxicity of their seeds and its negative effect on growth. Bitter vetch must not exceed $25 \%$ in the rations for sheep and cattle. It is very resistant to cold, because of its sparse habit and branching and slow growth (López Bellido 1994), as well as to drought, even in spring. A harvest is obtained even during excessively dry years. High grain yields (up to 3 t ha-1) may be obtained in favourable conditions. It is adapted to the regions with wide annual precipitation sums, ranging from $360 \mathrm{~mm}$ to $1160 \mathrm{~mm}$, prefers an annual mean temperature of $14^{\circ} \mathrm{C}$ and is suited to neutral or lightly acid soils, tolerating limy types of soil that are not too clayey.

A rich bitter vetch sample form Hissar differs from the rich Pisum sample only in the occurrence of charred items of spelt wheat (Triticum spelta L.), which is the first record of this wheat at Hissar, and in lack of pea seeds (Table 2). Reaching only $91 \%$ bitter vetch weight share is not as high as in the case of pea, the main reason for this being the increased weight share of barley. Nevertheless, the share of other legumes (such as lentil and broad bean) is insignificant in the sample. Just like pea from the same site, the bitter vetch from Hissar was cultivated as one of the main crops and stored separately from the other pulse crops. The thousand grain weight of its seeds is $11.74 \mathrm{~g}$. In contrast to pea, it is possible to compare these values with other sites in the region. At Agios Mamas, the 1000 ervilia seeds weigh normally under $10 \mathrm{~g}$ (Becker \& Kroll 2008), while at Feudvar they weigh as lens seeds, only $6.02 \mathrm{~g}$ (H. Kroll, pers. comm.). The weight of bitter vetch from Hissar fits into the range values from Kastanas, with 10-13 g (Kroll 1983).

\section{Storage Pests}

In the rich ervilia sample from Hissar, at least five seeds had large boreholes in the place of radicle. This fits the description made by
H. Kroll (1983) on the charred bitter vetches seeds found at the tell of Kastanas in northern Greece. Rich bitter vetch finds from Kastanas were defiled by seed beetles (Bracbinae). The infestation was not considerable, only $1-2 \%$. Seed beetles infestation of pulses was also recorded on several archaeological sites in Europe, Middle East and Egypt (Panagiotakopulu 2001). In the rich Pisum sample from Hissar one larva of a holometabolous insect was found. Many seeds were defiled (G. Duc, pers. comm.), possibly by pea beetle (Bruchus pisorum L.). Both bitter vetch and pea storages from Hissar were infested by pests. The history of crops is closely related to history of pests of stored products. With a fair record of pests on archaeological sites, one could be able to reconstruct original routes of their expansion through crop trade in the past.

\section{Soil, Climate and Biodiversity}

Geographically speaking, almost two thirds of the area surrounding Hissar are hills and valleys. The rest is flat, which, in a broader sense, constitutes the so-called Leskovac valley. The majority of soils, represented by various types of brown soils, are of medium-heavy mechanic content and medium porous. As per chemical content, the land is typically acid, while the content of humus is low, with a moderate share of physiologically active phosphorus and potassium. The climate is complex, where the main, typically continental conditions are mingling with the Mediterranean influences coming from the south, up the valley of the river Vardar and deeper into the hills and mountains of the south-central Balkans, where Leskovac is situated. A relatively low level of the total annual precipitation sum of between 600 $\mathrm{mm}$ and $800 \mathrm{~mm}$ represents the most important condition for agriculture.

This region is also extremely rich in plant biodiversity, making a continuum stretching from Asia Minor, over southern Bulgaria to the northern Albania and southern Montenegrin coast, with numerous crop wild relatives such as wild cereals and legumes. Considering the latter, it is only in the south, ranging from Niš, over Leskovac to Vranje, where wild pea (Pisum sativum subsp. elatius (Steven ex M. Bieb.) Asch. \& Graebn.) can be found in abundance in the whole Serbia, as well as wild lentil (Lens nigricans (M. Bieb.) Godr.) and numerous wild vetch species (Bojan Zlatković, pers. comm.).

It may be assumed that this specific constellation of the favourable soil and climatic conditions on one side and the extreme wealth of 
Table 2. Hissar, Leskovac, South Serbia, 2005, Sample 36. Macrofossil plant remains (charred seeds and one seeded fruits). Brnjica II a, 12th cent. B.C. - $\mathrm{r}<0.5 \%$;

$0.5 \%<+<1.0 \%$

Tabela 2. Hisar, Leskovac, južna Srbija, 2005, uzorak 36. Makrofoslini ostaci biljaka (ugljenisana semena i jednosemeni plodovi). Brnjica II a, 12. vek p.n.e.

\begin{tabular}{|c|c|c|c|c|}
\hline $\begin{array}{l}\text { Species } \\
\text { Vrste }\end{array}$ & $\begin{array}{l}\text { Quantitity } \\
\text { Količina } \\
\text { (No.) }\end{array}$ & $\begin{array}{l}\text { Quantitity } \\
\text { Količina } \\
(\%)\end{array}$ & $\begin{array}{l}\text { Mass } \\
\text { Masa } \\
(\mathrm{mg})\end{array}$ & $\begin{array}{c}\text { Mass } \\
\text { Masa } \\
(\%)\end{array}$ \\
\hline \multicolumn{5}{|l|}{ Cereals / Strna žita } \\
\hline Hordeum vulgare vulgare & 190 & 5.66 & 2683 & 6.83 \\
\hline Triticum monococcum & 14 & $\mathrm{r}$ & 116 & $\mathrm{r}$ \\
\hline T. monococcum, spikelet forks / glume bases & 1 & $\mathrm{r}$ & 1 & $\mathrm{r}$ \\
\hline Triticum dicoccon & 6 & $\mathrm{r}$ & 68 & $\mathrm{r}$ \\
\hline Triticum spelta & 5 & $\mathrm{r}$ & 55 & $\mathrm{r}$ \\
\hline T. spelta, spikelet forks / glume bases & 1 & $\mathrm{r}$ & 4 & $\mathrm{r}$ \\
\hline cf. Triticum aestivum s.l. & 4 & $\mathrm{r}$ & 45 & $\mathrm{r}$ \\
\hline Cerealia indeterminata & 47 & 1.40 & 466 & 1.19 \\
\hline \multicolumn{5}{|l|}{ Millets / Prosolika žita } \\
\hline Panicum miliaceum & 27 & + & 42 & $\mathrm{r}$ \\
\hline \multicolumn{5}{|l|}{ Pulses / Variva } \\
\hline Vicia ervilia & 3031 & 90.24 & 35589 & 90.64 \\
\hline Lens culinaris & 11 & $\mathrm{r}$ & 90 & $\mathrm{r}$ \\
\hline Vicia faba & 2 & $\mathrm{r}$ & 75 & $\mathrm{r}$ \\
\hline \multicolumn{5}{|c|}{ Weeds and ruderals / Korovske i ruderalne biljke } \\
\hline Polygonum convolvulus & 15 & $\mathrm{r}$ & 26 & $\mathrm{r}$ \\
\hline Asperula arvensis & 2 & $\mathrm{r}$ & 2 & $\mathrm{r}$ \\
\hline Chenopodium album & 2 & $\mathrm{r}$ & 0 & $\mathrm{r}$ \\
\hline Lactuca & 1 & $\mathrm{r}$ & 2 & $\mathrm{r}$ \\
\hline Total / Ukupno & 3359 & 100 & 39264 & 100 \\
\hline \multicolumn{5}{|l|}{ Wood charcoal / Ugljenisano drveće } \\
\hline Quercus & 6 & & 361 & \\
\hline Acer & 1 & & 53 & \\
\hline Total / Ukupno & 7 & & 414 & \\
\hline \multicolumn{5}{|c|}{ Thousand grain weight (g) / Masa hiljadu semena } \\
\hline Vicia ervilia & & 11 & & \\
\hline \multicolumn{5}{|c|}{ Mineralised seeds and onseeded fruits / Mineralizovana semena i semeno voće } \\
\hline Sambucus ebulus & 2 & & 2 & \\
\hline Total / Ukupno & 2 & & 2 & \\
\hline
\end{tabular}

wild and agricultural legume flora was the main reason why pulses have always been an important component in human diets and animal feeding as both voluminous and concentrated feed. Once, it was pea, lentil, bitter vetch, broad bean, grass pea (Latbyrus sativus L.) and chickpea (Cicer arietinum L.), while today it is common bean (Phaseolus vulgaris L.), gradually replacing the former ones during the last few centuries. At any rate, pulses were and still are there, in Leskovac and its heartland of the Serbian south, equally important as cereals, vegetables, meat and other basic nutrients.
Leskovac and its region is one of the last ancient European grain legume refugia in Serbia, where crops such as bitter vetch have been cultivated for forage and grain until relatively recently (Đorđević 1942) and where others such as broad bean still persist (Mihailović et al. 2010) and vetches are the most popular annual forage crop. Can an echo of the excavated and ringing countless bitter vetch and pea seeds from the past break the walls of oblivion and reintroduce these crops in the Serbian and Balkan agriculture, to the benefit of Europe and its diverse agro-ecosystems? 


\section{Conclusions}

Although pea is one of the first crops cultivated by man, a lucky find of 2,572 pea seeds in only one sample from Hissar represents a unique example in the archaeobotany of South East Europe. This amount of pea seeds could only be reached if hundreds of samples at one site are analysed. The reason for this should be seen not only in the fact that pulses generally have less chances of getting carbonized than cereals, and therefore are underrepresented in archaeobotanical record, but also in the difficult determination of Pisum seeds. Pea from Hissar was a distinct crop, stored separately from other crops. The status of pea in Hissar's Early Iron Age economy is disputable. According to its record's frequency, it seems that pea was cultivated on small patch-like fields. High 1000-grain weight of pea, with some restraints, seems to confirm the intense crop-care on small scaled areas.

On the other hand, the records of bitter vetch at archaeological sites in South East Europe are abundant. One of the reasons may be the fact that its well-rounded tetrahedron seeds are unique and therefore can be recognized easily. Ervilia, lentil and broad bean are most frequent pulse crops at Hissar. As well as pea, bitter vetch was cultivated and stored separately.

The constellation of agro-ecological factors, such as slightly acid soil and steppe-like climate with a low level of the precipitation with drought periods, favours bitter vetch production in the Leskovac valley over pea. Nevertheless, it is suitable for a large-scale cultivation of all pulse crops. Thus this region has become an epitome for the pulse production in modern Serbia, such as in a famous proverb used to describe an extremely tasty, truly delicious and masterfully prepared pulse dish of common bean: $O b$, yeab! This one's been a genuine 'Bean Tetovac - made in Leskovac!'

\section{References}

Becker C, Kroll H (2008): Das Prähistorische Olynth. Ausgrabungen in der Toumba Agios Mamas 1994-1996. Ernährung und Rohstoffhandel im Wandel. Verlag Marie Leidorf GmbH, Rahden/Westf.

Đorđević V (1942): Gajenje biljaka za stočnu hranu. Srpsko poljoprivredno društvo, Belgrade

Jones G, Valamoti S (2005): Lallemantia, an imported or introduced oil plant in Bronze Age northern Greece. Veg. Hist. Archaeobot. 14: 571-577

Kišgeci J, Medović A (2006): Prehistoric use of medicinal and aromatic plants in the southeast part of the Pannonian Plain. Proceedings, Third Conference on Medicinal and Aromatic Plants of Southeast European Countries, Belgrade, Serbia, 29-32

Kroll H (1983): Kastanas. Ausgrabungen in einem Siedlungshügel der Bronze- und Eisenzeit Makedoniens 1975-1979. Die Pflanzenfunde. Verlag Volker Spiess, Berlin

Kroll H (1991): Südosteuropa. In: Van Zeist W. et al. (eds.), Progress in Old World Palaeoethnobotany, Balkema, Rotterdam, the Netherlands, pp. 161-177

Kroll H (1998): Die Kultur- und Naturlandschaften des Titeler Plateaus im Spiegel der metallzeitlichen Pflanzenreste von Feudvar. In: Hänsel B, Medović P (eds.), Feudvar I. Das Plateau von Titel und die Šajkaška. Verlag Oetker-Voges, Kiel, Germany, pp. 305-317

López Bellido L (1994): Grain legumes for animal feed. In: Hernándo Bermejo J E, León J (eds.), Neglected Crops: 1492 from a Different Perspective. FAO, Rome, Italy, pp. 273-288

Medović A (2005): O biljnoj ekonomiji gradinskog naselja Hisar kod Leskovca, južno Pomoravlje, sa kraja bronzanog doba (oko 1350-1000 g. pre n.e). Leskov. zb. 45: 201-209

Mihailović V, Mikić A, Vasić M, Ćupina B, Đurić B, Duc G, Stoddard F L, Hauptvogel P (2010): Neglected legume crops of Serbia - Faba bean (Vicia faba). Ratar. Povrt. / Field Veg. Crop Res. 47: 27-32

Oelke E A, Oplinger E S, Hanson C V, Davis D W, Putnam D H, Fuller E I, Rosen C J (1991): Dry Field Pea. Alternative Field Crops Manual. University of Wisconsin Cooperative Extension Service, the University of Minnesota Extension Service and the Center for Alternative Plant and Animal Products

Panagiotakopulu E (2001): New Records for Ancient Pests: Archaeoentomology in Egypt. J. Archaeol. Sci. 28: 1235-1246

Stojić M, Pešić J, Jović S (2007): Kulturna stratigrafija arheološkog lokaliteta Hisar u Leskovcu. Leskov. zb. 47: 29-40 


\title{
Grašak i urov Tetovac - made in ranogvozdenodobni Leskovac. Deo prvi. Dve zalihe ugljenisanih zrnastih mahunarki sa gradinskog naselja Hisar kod Leskovca, južno Pomoravlje
}

\author{
Aleksandar Medović ${ }^{1}$ Aleksandar Mikić ${ }^{2}$ Branko Ćupina B Živko Jovanović $^{4}$ \\ - Svetlana Radović ${ }^{5}$ Aleksandra Nikolić $c^{4}$ Nemanja Stanisavljević ${ }^{4}$
}

\begin{abstract}
${ }^{1}$ Muzej Vojvodine, Dunavska 35, 21000 Novi Sad, Srbija
${ }^{2}$ Institut za ratarstvo i povrtarstvo, Maksima Gorkog 30, 21000 Novi Sad, Srbija

${ }^{3}$ Poljoprivredni fakultet Univerziteta u Novom Sadu, Trg Dositeja Obradovića 8, 21000 Novi Sad, Srbija

${ }^{4}$ Institut za molekularnu genetiku i genetičko inženjerstvo Univerziteta u Beogradu, Vojvode Stepe 444a, p.fah 23, 11010 Beograd, Srbija

${ }^{5}$ Biološki fakultet Univerziteta u Beogradu, Studentski trg 16, 11000 Beograd, Srbija

Izvod: Arheološki lokalitet Hisar je gradinsko naselje Brnjičke kulturne grupe (gvozdeno doba I u Pomoravlju), podignuto na vrhu, odnosno na platou brda Hisar koje kontroliše zonu ušća Jablanice i Veternice u Južnu Moravu i najveći deo Leskovačke kotline. Prilikom arheoloških istraživanja 2005. godine u objektima koji se vezuju za Brnjica II a fazu (12. vek pre nove ere) pronađene su dve velike količine ugljenisanih semena graška (Pisum sativum L.) i urova (Vicia ervilia (L.) Willd.). Zalihe ove dve zrnaste mahunarke bile su skoro čiste, sa malim procentom nečistoća koje su pre svega činili plodovi, pre svega žitarica, drugih mahunarki (sočivo - Lens culinaris Medik. i bob - Vicia faba L.), ali i biljaka uljarica, što ukazuje da su grašak i urov bili odvojeno uzgajani, a potom i odvojeno skladišteni. Ovi nalazi, a pre svega nesvakidašnji nalaz zalihe graška, potvrđuju dugu tradiciju uzgajanja mahunarki u leskovačkom kraju. Ključne reči: 12. vek p.n.e, arheobotanika, Brnjička kulturna grupa, Hisar, južna Srbija, Leskovac, zaliha ugljenisanog semena graška, zaliha ugljenisanog semena urova
\end{abstract}

